Submitted draft

\title{
Intelligence-Led Policing: Comparing National Approaches to its Regulation and Control
}

\section{Introduction}

Intelligence-led policing (ILP) strategies are significant elements in modern policing arrangements. ${ }^{1}$ For some, policing's enthusiasm for ILP is emblematic of 'surveillance society' and its attendant iniquities. ${ }^{2}$ Others argue that even though some of the strategies commonly associated with the term may be unpalatable; the need for ILP simply is a pragmatic reality. It is a necessary evil justified by the increasing dangerousness of the social world. 3 Policymakers' enthusiasm for alternative models indicates an international transformation of public policing. Such significant change gives rise to a number of questions. Not least, in this new policing paradigm: do normative checks and balances provide sufficient protection for citizens' rights; to what extent does this reconfiguration threaten the legitimacy of public policing; and, finally, should there be cross-jurisdictional harmonization of ILP-related law and regulation?

\section{Public policing}

A significant and enduring feature of the social contract is that support for the police institution always is conditional. Public policing has many aspects. Police prevent crime; deterring potential law-breakers, to keep communities safe. They enforce the

\footnotetext{
${ }^{1}$ See J-P Brodeur, The Policing Web (Oxford University Press 2010); JH Ratcliffe, Intelligence-led policing ( $2^{\text {nd }}$ edn, Routledge 2016); and A James, Understanding police intelligence work (Policy Press 2016).

${ }^{2}$ See D Lyon, Surveillance Society: Monitoring Everyday Life (Open University Press 2001).

3 See GT Marx, Undercover: police surveillance in America (University of California Press 1988); A James Examining intelligence-led policing (Palgrave Macmillan 2013); and H Carrapiço; D Irrera; and B Tuman Criminals and terrorists in partnership: unholy alliance (Routledge 2015).
} 


\section{Submitted draft}

law; intervening in conflict situations to apprehend those they identify as offenders. Police officers are bound by the rule of law. Their work commonly is authorized by common law, positive law or regulation, which inter alia enables monitoring of the conduct of the institution and its members.

Ordinarily, policing takes place in public. In principle, rule infractions can easily be identified and remedies applied where appropriate. 4 It is debateable whether the same can be said for ILP activities, which may be extraordinary and often are hidden from public view. It is not by accident that, in most liberal democracies, law significantly limits the ability of intelligence staff to conduct their activities. Broadly, it is understood that citizens are entitled to 'protections and rules of process based on the basic compact between the people and the government' no matter how transparent (or opaque) police action may be. 5

\section{Intelligence Led Policing}

In the modern era, threats to nation states from professional criminals, criminal networks and terrorists have created environments in which politicians and policymakers more readily turn to information-based instruments of control. Substantially, ILP implies a shift from traditional reactive 'fire-brigade' style policing to a proactive approach founded on the systematic collection, evaluation, and analysis of information. Encouraged by their political overseers, police institutions have embraced the information collection opportunities that ILP affords, with

\footnotetext{
4 See for example M Punch, Police corruption and its prevention in European Journal on Criminal Policy and Research, [2000] 8(3), 301; CB Klockars; SK Ivkovic; and MR Haberfeld, The contours of police integrity (Sage 2004).

5 FF Manget, Intelligence and Law Enforcement in LK Johnson (Ed), The Oxford Handbook of National Security Intelligence (Oxford University Press 2010, 189) 189-90.
} 
Submitted draft

enthusiasm. ${ }^{6}$

Information management underpins modern ILP. Traditionally, the collection, filtering and sorting of information by public police forces was predicated on the need to meet the ordinary expectations of the criminal justice community and other stakeholders. Those activities were complementary but often incidental to the institution's crime-fighting, peacekeeping and service delivery roles. Now, they are considered vital components in the formulation of policing and security plans. ${ }^{7}$

A police department's commitment to ILP implies that it prioritizes, and mainstreams its information management processes. ${ }^{8}$ It suggests that organizational energy is committed to using intelligence to direct policing plans.9. Largely, that translates into the targeting of groups and individuals suspected of committing (or planning to commit) criminal offences. In the post 9/11 world, those targeting processes have moved centre-stage as governments and state institutions increasingly place their trust in ILP as their best strategy for filling security gaps. ${ }^{10}$

\section{ILP methodologies}

Commonly used ILP methodologies include: interception of communications (capturing the content of a telephone call, letter or digital communication); collection

\footnotetext{
${ }^{6}$ See JH Ratcliffe Ibid.

7 See M den Boer, Intelligence Exchange and the Control of Organised Crime: From Europeanisation via Centralisation to Dehydration, in J. Apap and M. Anderson (Eds.) Police and Justice Co-operation and the New European Borders (Kluwer Law International 2002).

${ }^{8}$ See JH Ratcliffe Ibid.

9 See C Harfield and K Harfield, Intelligence, Investigation, Community and Partnership, (Oxford University Press 2008); and A James Ibid.

${ }^{10}$ See N Tilley, Intelligence-led policing and disruption of organized crime: motifs, methods, and morals in T Delpeuch and JE Ross (Eds.) Comparing the Democratic Governance of Police Intelligence: New Models of Participation and Expertise in the United States and Europe, (Edward Elgar 2016).
} 


\section{Submitted draft}

of communications data (including their: duration; time; source and destination address, and so on); surveillance (the monitoring and/or recording of the movements of groups and individuals); and the use of informers or undercover police officers.

More recently, ILP has developed to embrace new tools such as: biometric and drone technologies, the acquisition of data generated through the use of social media, and the investigation of encrypted electronic data. The use of such techniques often result in police officers infringing upon citizens' land or property in circumstances that would ordinarily be labelled as criminal. For example, in many nations, the police routinely interfere with privately-owned motor vehicles to deploy tracking and monitoring devices. ${ }^{11}$

\section{Tactical convergence}

Today, there is ample evidence of convergence in practice; ILP techniques are used around the world. Though of course the legal, political, and social contexts in which they are employed vary considerably. ${ }^{12}$ Rather more consistently, it is at the nexus point where police and public meet, that human factors are of the greatest significance. It may be argued, justifiably, that the overwhelming majority of police/public interactions are unproblematic; the police act in lawful and procedurally fair ways. Equally, it is accepted that in the collective consciousness of

\footnotetext{
${ }^{11}$ See for example Uzun v. Germany [2010] app. 35623/o5.

12 See GT Marx (Ibid.); M Innes and J Sheptycki, From detection to disruption: intelligence and the changing logic of police crime control in the United Kingdom in International Criminal Justice Review [2004] 14(1); and J Grieve, Developments in UK criminal intelligence in J Ratcliffe (Ed) Strategic Thinking in Criminal Intelligence (Federation Press 2004).
} 


\section{Submitted draft}

some communities, the idea that police officers will resort to rule-bending to get things done when the means are not justified, is well-established. ${ }^{13}$ Rule-bending and 'cover-ups' are far from unknown. ${ }^{14}$ It follows, that if disproportionate, unnecessary or illegal police activity is to be identified, it is in the context of low visibility ILP that legislative certainty and vigorous oversight are needed the most.

\section{Controlling ILP}

Internal controls on police behaviour always have existed. ${ }^{15}$ They are consistent and enduring features of rational-legal bureaucracies but in the information age, some question their continuing appropriateness. ${ }^{16}$ Many nation states have replaced, or at least supplemented, internal ILP rules with statutory controls. The UK's Police Act, ${ }^{17}$ and Regulation of Investigatory Powers Act (RIPA), ${ }^{18}$ the Netherlands' introduction of its Special Investigative Police Powers Act, ${ }^{19}$ and Canada's enactment of its AntiTerrorism Act, ${ }^{20}$ are examples of the legitimization of activities long undertaken but increasingly challenged, on constitutional or human rights grounds, by jurists and campaigners. ${ }^{21}$ In some cases, (as in the UK example) legislation is supplemented with oversight mechanisms that are designed to provide intrusive supervision both of

\footnotetext{
13 Apocryphally, the 'Ways and Means Act' is a fictional statute cited by police officers to justify their actions when legal means are unavailable.

14 See for example PK Manning, Police Lying, Journal of Contemporary Ethnography [1974] 3(3); and; M Rowe; L Westmarland and C Hougham, Getting Behind the Blue Curtain in Accountability of Policing, Routledge Frontiers of Criminal Justice, (Taylor \& Francis 2015).

15 See for example DPJ Walsh, Intelligence and intelligence analysis (Routledge 2011).

16 See N Tilley, Intelligence-led policing and disruption of organized crime: motifs, methods, and morals in T Delpeuch and JE Ross (Eds.) Comparing the Democratic Governance of Police Intelligence: New Models of Participation and Expertise in the United States and Europe (Edward Elgar 2016).

17 UK, 1997, C.50.

18 UK RIPA, 2000, C.23.

19 Netherlands, 2014 Aoo9

${ }^{20} \mathrm{SC}, 2001, \mathrm{c} .41$.

${ }^{21}$ See S McKay, Covert Policing Law and Practice (2 ${ }^{\text {nd }}$ Edn, Oxford University Press, 2015).
} 
Submitted draft

judicially-authorized and extra-judicial ILP activity. ${ }^{22}$

\section{Higher level norms}

Higher-level norms (such as legitimacy, fairness and equality) always are germane to debates about the use of ILP methods and strategies. In democracies that claim the epithet 'liberal', these principles invariably are reflected in national legislation. Whether those rights are protected by constitution (as in the United States of America), by charter (in Canada), by treaty (such as the Charter of Fundamental Rights of the European Union - given full legal force by the Lisbon Treaty), ${ }^{23}$ or by convention (such as the European Union's Convention on Mutual Assistance in Criminal Matters),24 compliance with higher level norms is guaranteed only when the institution's actions (or proposed actions) demonstrably are necessary, proportionate, and legal.

Those who feel that the state's agents have acted unconstitutionally or have violated basic human rights, may seek redress in nations' supreme or constitutional courts. In Europe, the court of arbitration is the European Court of Human Rights (ECtHR), which has been a significant driver of legislative and procedural change. For example, its judgement in Govell vs. the UK [App. 27237/95, 14 January 1998] and Khan vs. the UK [2001, 31 EHRR 1016] led to the statutory regulation of audio surveillance in the UK. While judgements such as Kopp vs. Switzerland [App. 13/1997/797/1000, 25 March 1998], and Natunen v Finland [App. 21022/04, 31

\footnotetext{
${ }^{22}$ See C Harfield and K Harfield Ibid.

${ }_{23} \mathrm{EU} \mathrm{2007/C} \mathrm{306/01}$

24 EU 2000/C 197/O1
} 
Submitted draft

March 2009] provided clarity around nation states' rights to intercept citizens' communications.

ILP tactics invariably are controversial and their use routinely is contested. ${ }^{25}$ Though those contests ultimately may play out in supra-national forums (like the ECtHR), the extent to which ILP is lawful, usually is decided in the first instance by national legislatures where legislation invariably reflects national interests, beliefs, social norms, cultures, attitudes and so on. Even if, universally, at a philosophical level there may be tacit agreement on the need for controls. Jones and others note that, substantially, research of policing and justice systems suggests that one cannot conceive of 'simplistic pictures of cross-national convergence on the one hand or the stubborn persistence of national difference on the other'. ${ }^{26}$ In that context, the existence of bodies like the ECtHR, is essential if an international consensus is ever to be reached.

\section{Subsidiarity}

With its roots in Catholic theology, subsidiarity is a significant tenet of the constitutional discourse of legal systems around the world. ${ }^{27}$ In Europe, the principle was formally enshrined by the Maastricht Treaty, which established the European Community. ${ }^{28}$ Its aims were bold; adherence to the principle, is intended to guarantee a more efficient Europe, closer to citizens and respectful of localism and

\footnotetext{
${ }^{25}$ See JE Ross, The Place of Covert Surveillance in Democratic Societies: A Comparative Study of the United States and Germany (2007). American Journal of Comparative Law, 55(3), 579.

${ }^{26}$ T Jones; R van Steden; and H Boutellier, Pluralization of policing in England \& Wales and the Netherlands: exploring similarity and difference. Policing \& Society [2009] 19(3), 283.

${ }^{27}$ See PG Carozza, Subsidiarity as a structural principle of international human rights law. American Journal of International Law [2003], v.101, 39.

${ }^{28}$ Treaty on European Union, OJ C 191 of 29/7/1992.
} 
Submitted draft

national identity. Explained as the basis for limited government, subsidiarity warns against the overbearing action of nation states and other influential social actors.

In the context of ILP, it cautions the police against turning to intrusive methods unless others have been tried and failed or when circumstances suggest that, were they attempted, they would not succeed. Even then, the police should use the least intrusive method available. In many countries, maintenance of citizens' rights and freedoms may be understood as being reliant upon post hoc - usually judicial - oversight of practitioner's decisions but they also depend upon relevant professionals': knowledge; reflection; and skills.

Because so many policing decisions are taken at the lowest level of the institution there is a direct and significant link between individual competence and constitutional freedoms. ${ }^{29}$ Sub-optimal levels of professional knowledge, expertise, and so on, are almost bound to deliver decisions that threaten citizens' rights and liberties. They also present substantial reputational risks to state institutions like the public police. 30

\section{Relevant cases}

This selection of cases, supports Jones and others argument about the unevenness of legislative controls but they also seem to confirm the international trend towards statutes that recognize the constitutional challenges presented by ILP. ${ }^{31}$ Any meaningful analysis in this context should begin with an examination of

\footnotetext{
$29 \mathrm{~J}$ Kleinig, Handled with discretion: ethical issues in police decision making (Rowman \& Littlefield 1996).

${ }^{30} \mathrm{R}$ Ericson, Ten uncertainties of risk-management approaches to security (2006). Canadian Journal of Criminology and Criminal Justice [2006] 48(3), 345.

${ }^{31}$ T Jones; R van Steden; and H Boutellier Ibid.
} 
Submitted draft

developments in the US. The September 2001 terrorist attacks sent a shockwave not only through the US but through the legislative systems of nation states around the world.$^{2}$ The international convergence of formerly nation-specific approaches that followed, is an important strand in the ILP narrative.

\section{United States of America}

In the aftermath of 9/11, the Bush administration's declaration of a 'War on Terror' stimulated a substantial expansion of intelligence collection activity by nation states and their agents. The temporary powers granted to US social control agencies by the Patriot Act, 2001,33 enhanced wiretap authorities and extended the police's ability to record citizens' telephone communications and to carry out covert searches of premises. 34 William Bloss argues that the Act signified 'a change of course in the legislation designed to enhance police surveillance and search capability'.35

US policing is regulated by constitutional, case, and statutory, laws. The exercise of surveillance, search, and seizure powers are governed by the Fourth Amendment to the US Constitution (which contains legal principles that guide police activity in those contexts) and by civil liberty principles, which establish safeguards against unreasonable police behaviour. The extent to which the new powers were compatible with those higher-level norms was challenged almost from the outset. Michael Dowley argues that a constitutionally acceptable balance between security

\footnotetext{
$3^{2}$ EJ Husabø, Counterterrorism and the Expansion of Proactive Police Powers in the Nordic States, Journal of Scandinavian Studies in Criminology and Crime Prevention [2013] 14(1), 3. 33 In 2006, the temporary provisions were entered permanently into federal statute via the USA PATRIOT Act, Additional Reauthorizing Amendments Act - S. 2271 (109 $\left.{ }^{\text {th }}\right)$.

34 WP Bloss, Transforming US police surveillance in a new privacy paradigm (2009). Police Practice and Research: An International Journal [2009] 10(3), 225.

35 Bloss Ibid, 229.
} 


\section{Submitted draft}

and civil liberties is possible but the evidence suggests that the balance is tilted in favour of the state. $3^{6}$ For example, in 2014, it was revealed that agencies were making extensive use of the 'sneak and peek' powers granted under the Act.37 From September 2001 to April 2003, 47 searches were carried out nationwide. In 2010, 3,970 requests were processed. Within three years that number increased to 11,129 . It was found that relevant powers were used as an everyday investigative tool rather than in exceptional circumstances as legislators had intended. ${ }^{8}$ In fact, the powers were used in only a very small minority of cases involving terrorism. 39

\section{Canada}

The rights of Canadian citizens are protected by the Canadian Charter of Rights and Freedoms.40 Effective June 21, 1984, the Charter replaced the Canadian Bill of Rights and now forms an important part of the Canadian Constitution. Murphy argues that in the wake of the 9/11 attacks, a "highly politicized "insecurity discourse" emerged' ... [this was] designed to educate and persuade Canadians to support a more aggressive national security [and, by extension, policing] agenda. ${ }^{41}$ As one of the US's closest neighbours and firmest allies, it was only natural that the Canadian

\footnotetext{
${ }^{36}$ M Dowley, Government Surveillance Powers under the USA Patriot Act: Is It Possible to Protect National Security and Privacy at the Same Time - A Constitutional Tug-of-War, Suffolk University Law Review, [2002] 36(1), 165.

37 Section 213 of the Patriot Act granted law enforcement agencies the power to conduct a search while delaying notice to the suspect of the search.

${ }^{8} 8$ EFF, Peekaboo, I See You: Government Authority Intended for Terrorism is used for Other Purposes (2014). Available at https://www.eff.org/deeplinks/2014/10/peekaboo-i-see-yougovernment-uses-authority-meant-terrorism-other-uses 39 R Balko, Surprise! Controversial Patriot Act power now overwhelmingly used in drug investigations. (29 October 2014). Washington Post online at https://www.washingtonpost.com/news/the-watch/wp/2014/10/29/surprise-controversial-patriotact-power-now-overwhelmingly-used-in-drug-investigations/ Accessed 14/9/2017.

$4^{40}$ Canada Act 1982 [U.K.].

${ }^{41}$ See C Murphy, Securitizing' Canadian Policing: A New Policing Paradigm for the Post 9/11 Security State? (2004) Australian \& New Zealand Journal of Criminology [2004] April, 37(1), 155.
} 
Submitted draft

government would support it at a time of crisis.

In 2001, Canada passed its Anti-Terrorism Act.42 David Schneiderman argued that the Act was a necessary response to living in an increasingly risk society even though it limited many of the freedoms traditionally enjoyed by citizens. 43 The Act significantly expanded ILP powers in Canada.44 Essentially, it became easier for public police to obtain search warrants, detain suspects without charge, and extend their surveillance activities. Significantly, as grounds for police action, it substituted 'reasonable belief' with the less rigorous test of 'reasonable suspicion'.45

Jennifer Stoddard, then Canada's Privacy Commissioner was one of a number of commentators to highlight the threats to civil liberties inherent in this allencompassing piece of legislation. ${ }^{46}$ She warned that if the logic of anti-terrorism was allowed to permeate all aspects of policing and safety, 'large scale systems of surveillance will increasingly erode privacy rights in Canada, without critical assessment where it is appropriate to draw the line'. 47

Arguably, the Royal Canadian Mounted Police's (RCMP) actions in conducting operations against 89 Canadian citizens - all members of the same racial group associated with protests against the development of natural resources, are the kinds of human rights abuses Stoddard had in mind. 48 The RCMP's own report on those events, accepted the need for organizational change that ensured, 'peaceful and law-

\footnotetext{
42 Anti-Terrorism Act, 2015 (Bill C-51) S.C. 2015, c. 20.

43 In E Zureik with K Hindle, Governance, Security and Technology: the case of biometrics, Studies in Political Economy 73 [2004] Spring/Summer 2004, 113.

44 See V Steeves and V Piňero V, Privacy and Police Powers: Situating the Reasonable Expectation of Privacy Test, Canadian Journal of Criminology and Criminal Justice [2008] 50(3), 263.

45 C Murphy Ibid.

46 Cited in C Murphy Ibid, 464.

47 C Murphy Ibid.

$48 \mathrm{~J}$ Barrera, RCMP intelligence centre compiled list of 89 indigenous rights activists considered 'threats'. National News, 8 November 2016 at http://aptn.ca/news/2016/11/o8/rcmp-intelligencecentre-compiled-list-of-89-indigenous-rights-activists-considered-threats/ Accessed 14/9/2017
} 
Submitted draft

abiding individuals engaged in acts of legitimate dissent' would not be investigated or analysed' in the future. 49

\section{The Nordic States}

Erling Husabø argues that a significant feature of Nordic criminal justice systems after 9/11 was a 'shift in focus from a retrospective to a prospective use of criminal law'.50 That was only natural. In any calculation of threat, risk or harm; the opportunity to prevent a criminal act (particularly a terrorist act) invariably will be prioritized over waiting for the act to take place and then dealing with its aftermath but any move towards a more proactive approach was bound to have a substantial impact on the broader criminal law. Such was the case in the Nordic states, which saw the same expansion in the use of 'extraordinary' police powers witnessed in the other cases examined here. 51

In Sweden, the initial policy impetus that followed 9/11, 'petered out by 2003', but - it is argued - was reinvigorated by the Madrid bombings which had a deeper impact in the EU as a whole than the 9/11 attacks.52 There was an element of 'pushback' in some states. For example, covert audio surveillance of private rooms was accepted, and legislated for, in Denmark and Iceland but not in Sweden or Norway.

\footnotetext{
49 Royal Canadian Mounted Police, Project SITKA: serious criminality associated to large public order events with national implications. RCMP 2015, 24)

50 EJ Husabø Ibid.

${ }^{51}$ See for example EJ Husabø Ibid.

$5^{2}$ V Strandh and N Eklund, Swedish Counterterrorism Policy: An Intersection Between Prevention and Mitigation? [2015] Studies in Conflict \& Terrorism; 38(5), 359.
} 


\section{Submitted draft}

Though largely, as in the other cases examined here, states have chosen to move in a direction that has delivered more intrusion even if there is more regulation.53

\section{The United Kingdom}

Scholars agree that the roots of ILP can be found in the UK.54 The notion that intelligence analysis, the increasing specialization of the police workforce and the adoption of tools and techniques usually associated with the higher policing function - activity in the cause of protecting/maintaining the state - could revolutionize policing had taken hold long before 9/11.55 Since the 1980s, the UK's traditional faith in the philosophy of policing by consent, underpinned by a common-law tradition of implicit police power, was eroded as policing gradually was subjected to formal, often statutory, controls.

Just as in the other cases examined here, the terrible events of 9/11 accelerated the state's investment in the formal ILP mechanisms that emerged in the 1990 (following the publication of the Audit Commission's report). Regulatory clarity around these activities was provided by the introduction of RIPA. The Act was welcomed for the transparency it brought to covert policing activities; introducing new systems of governance and oversight for traditionally secret practices such as: the recruitment of informers, the interception of communications, the recording of

\footnotetext{
53 See EJ Husabø and I Bruce, I, Fighting Terrorism through Multilevel Criminal Legislation: Security Council Resolution 1373. EU Framework Decision on Combating Terrorism and their Implementation in Nordic, Dutch and German Criminal Law (Martinus Nijhoff 2009). 54 See N Tilley Ibid; B Harbisher, Unthinking Extremism: Radicalizing Narratives that Legitimize Surveillance, Surveillance \& Society [2015] 13(3/4), 474; and Ratcliffe 2016 Ibid. 55 See J-P Brodeur, High and Low Policing: Remarks about the Policing of Political Activities Social Problems [1983] 30(5), 507 and UK Audit Commission, Helping with enquiries: tackling crime effectively (Audit Commission 1993)
} 
Submitted draft

communications data, and surveillance. $5^{6}$ The UK also witnessed the same extension (observed in the USA and Canada) of the use of 'extraordinary' policing methods into the mainstream. For example, in the period April 2015 to March 2016, UK law carried out at least 7,000 surveillance operations (with more than 1,000 authorizations to conduct surveillance in force at year's end.57

In the UK too, environmental protest was considered an appropriate target for ILP. Regardless of the RIPA-inspired oversight arrangements, that fact largely remained hidden from public view until 2010 when the discovery of inappropriate relationships between undercover officers and activists led to the premature ending of a high-profile court case. The police's evidence collection methods were deemed lawful but an internal review found that the level of intrusion into activists' private lives was so excessive they were barely legitimate..$^{8}$ Concerns over the efficacy of that action were confirmed when it was discovered that an undercover officer had fathered an activist's child.59 Concrete proposals for reform of an oversight regime that permitted these kinds of deployments soon followed.6o

The result was a new Investigatory Powers Act. ${ }^{61}$ Portrayed by the UK's Home Secretary as 'world-leading legislation that provides unprecedented transparency and substantial privacy protection', the new Act addresses some of the concerns

\footnotetext{
${ }^{56}$ See A James Ibid. and JH Ratcliffe Ibid.

${ }^{57}$ See UKOSC, Annual Report of the Chief Surveillance Commissioner to the Prime Minister and to the Scottish Ministers (OSC, 2016).

${ }^{8} \mathrm{HMIC}$, Inspection of undercover policing in England and Wales (HMIC 2014).

59 A fact recognized by the officer's employers only in October, 2014 when the Metropolitan Police announced that it would make a payment of $£ 425$, 000 to the child's mother. See G Cooper, Bob Lambert, undercover cops, and the awful cost of sleeping with the enemy. Daily Telegraph (25 October 2016) (online) at http://www.telegraph.co.uk/news/uknews/law-and-order/11185926/BobLambert-undercover-cops-and-the-awful-cost-of-sleeping-with-the-enemy.html. Accessed 14/9/2017. ${ }^{60}$ See D Anderson, A Question of Trust - Report of the Investigatory Powers Review (Anderson 2015) and RUSI, A Democratic Licence to Operate Report of the Independent Surveillance Review (RUSI 2015).

${ }^{61}$ UK Investigatory Powers Act 2016, C.25.
} 


\section{Submitted draft}

expressed by lobbyists and jurists but - despite its relatively smooth passage through Parliament and onto the statute book - to many, it is little more than a 'snoopers' charter'. ${ }^{62}$ Not least, because many its reforms seem to continue the international trend, in this context, of extending state power. One of the Act's fiercest critics; Bella Sankey, the policy director of civil liberties group Liberty, said that, with its 'eyewateringly intrusive powers and flimsy safeguards... [the Act served] as a beacon for despots everywhere'. 63

\section{The Netherlands}

The Dutch National Intelligence Model was adopted in 2008.64 Officials believed ILP would add value to public order management, law enforcement, and policing's ability to respond to emergencies. 65 This led to increasing use of new technologies for crime prevention and surveillance, which became 'commonly accepted aspects of everyday situations in Dutch urban settings' ${ }^{66}$ Marielle den Hengst-Bruggeling and others note that security concerns, driven by the 9/11 attacks and the later bombings in London and Madrid heightened security fears at the same time as the police were being forced to reassess their ability to continue to meet the expectations of communities in an age of public sector austerity; creating a kind of 'perfect storm'. ${ }^{67}$

\footnotetext{
62 Amber Rudd in A Griffin, Investigatory Powers Bill Passes into Law. The Independent (online) (29 November 2016) at http://www.independent.co.uk/life-style/gadgets-and-tech/news/investigatorypowers-bill-snoopers-charter-passed-royal-assent-spying-surveillance-a7445276.html Accessed $14 / 9 / 2017$

63 In A Griffin Ibid.

64 See M den Hengst and E Staffeleu, Different Information Organizations to Produce the Same High Quality Intelligence: An Overview of the Police Forces in the Netherlands, 2012. Policing, 6(2), 187. 65 See M den Hengst-Bruggeling; B De Graaf; and P Van Scheepstal, Modelling intelligence-led policing to identify its potential European Journal of Policing Studies [2014] 1(3), 171.

66 J Terpstra and K van der Vijver The Police, Changing Security Arrangements and Late Modernity: The Case of the Netherlands (2006). German Police Studies, [2006] 5(1), Spring, 80. $67 \mathrm{M}$ den Hengst-Bruggeling and others, Ibid.
} 
Submitted draft

Until 2000, the Dutch criminal code did not specifically cover the kinds of techniques usually associated with ILP. ${ }^{68}$ This changed after a parliamentary investigation into the operations of the Netherlands' interregional, organized crime investigation teams, which was highly critical of the oversight and control of their operations. The response to the committee's recommendations was the Special Investigative Police Powers Act, 2000, which regulates investigative powers (including covert powers), providing both enhanced oversight and transparency. ${ }^{69}$

Researchers such as Dermot Walsh and Vicky Conway, and Kruisbergen and others, have challenged ILP's opaqueness, arguing that the police need to make a stronger case for its use. ${ }^{70}$ The latter argue that information should be made available so that basic monitoring of those activities can be carried out. So that, for example, even though ILP operations may not in practice be 'controllable', they can and should - be made more 'verifiable and accountable'.71

\section{Contextualising ILP}

Arguably, in liberal democracies; legislators and policymakers, on the one hand, and those committed to the protection of constitutional rights, on the other are participants in a Manichean struggle over the proper limits of state control and the exercise of police powers. In part, that conflict is mediated by national legislators, by

\footnotetext{
${ }^{68}$ EW Kruisbergen; D de Jong; and ER Kleemans, Undercover Policing: Assumptions and Empirical Evidence British Journal of Criminology [2011] 51(2), 394.

${ }^{69}$ Netherlands, Wet bijzondere opsporingsbevoegdheden, (Wet BOB) 1 February, 2000.

70 See DPJ Walsh and V Conway, V, Police Governance and Accountability: Overview of Current Issues Crime, Law and Social Change [2011] 55(2-3), 241; and EW Kruisbergen; ER Kleemans; and D de Jong, Controlling Criminal Investigations: The Case of Undercover Operations Policing, Volume [2012] 6(4), 398.

${ }^{71}$ EW Kruisbergen and others 2012, Ibid.
} 


\section{Submitted draft}

police departments, and by officers themselves but the theme that dominates that narrative is the extension rather than the limiting of police powers; ${ }^{2}$ justified as a response to threats to those societies posed by wicked problems such as terrorism and the like.73

The cases examined here suggest a reconfiguring of public policing as commonly accepted goals are replaced with those of disruption and dislocation. 74 Disruption has been core business for security services and armed forces for many years; usually as a component of wider counter-insurgency strategies.75 It also has been a common feature of totalitarian policing regimes. ${ }^{76}$ Increasingly, it seems to be an accepted method of policing in democratic societies. 77

\section{The ILP brand}

With an ever-expanding fan base and name recognition worldwide, the ILP brand resonates strongly with those who see the primary purpose of policing as crime control. The optimism, positivity and dynamism that routinely have come to be associated with the brand, distinguish it from other policing strategies. It has created a lasting and positive impression in the minds of policymakers and practitioners. ${ }^{78}$ For many, ILP represents a smarter form of policing that energizes staff and

\footnotetext{
${ }^{72} \mathrm{G}$ Mythen and S Walklate, Criminology and terrorism which thesis? Risk society or governmentality? British Journal of Criminology [2006] 46(3), 379.

73 Wicked problems - 'that class of problems which are ill-formulated, where the information is confusing, where there are many decision makers and clients with conflicting values, and where the ramifications in the whole system are confusing' ( $N$ Wittel cited in Churchman, 1967 p.B141)

74 See C Harfield and K Harfield Ibid; JH Ratcliffe Ibid; and N Tilley Ibid.

75 N Tilley Ibid.

${ }^{76} \mathrm{~J}$ Gieseke, The Stasi and East German Society: Some Remarks on Current Research Bulletin of the German Historical Institute, Supplement [2014] 9, 59.

77 J-P Brodeur cited in N Tilley Ibid.

${ }^{78} \mathrm{~J}$ Ratcliffe Ibid.
} 
Submitted draft

demonstrates to stakeholders and communities, the institution's ability to fuse technological, organizational, and human skills to transform practice.

Publicly, ILP has few critics. Arguably, for the institution, it is the perfect policing strategy because it prioritizes action, which for many 'street cops', and even for some 'management cops', is their professional raison d'etre. 79 A brand can confer a value on a product that exceeds its functional purpose. The ILP brand is distinguished from other policing strategies by its explicit link with intelligence and its more nuanced but perhaps obvious links with the technological advances that are characteristic of the information age. Its endorsement by high profile, influential, international bodies such as Interpol, Europol, the US Department of Justice, the United Nations Office on Drugs and Crime (UNDOC) and the Organization for Security and Cooperation in Europe (OSCE), have only added further lustre to ILP's reputation as the epitome of smart, innovative, intelligent, policing.

Christopher Murphy argues that its rhetoric of success resonates powerfully with communities and 'validates the trend to broader domestic intelligencegathering and analysis'. ${ }^{80}$ Its many adherents across the world certainly seem disposed to invest heavily in the emerging technologies of the information age and to channel scarce resources to it. ${ }^{81}$ That is not to say that support for ILP is universal; for many police insiders, ILP is both undesirable and unwelcome because it detracts

\footnotetext{
79 E Reuss-Ianni, Two cultures of policing: street cops and management cops. (Transaction Publishers 1993).

8o C Murphy, C, Securitizing' Canadian Policing: A New Policing Paradigm for the Post 9/11 Security State? Australian \& New Zealand Journal of Criminology [2004] April 37(1), 155.

${ }^{81}$ See B Flood, Strategic aspects of the UK National Intelligence Model in J Ratcliffe (Ed), Strategic Thinking in Criminal Intelligence (Federation Press 2003, 37); New Jersey State Police, Practical Guide to Intelligence-led Policing (2006) at https://www.ncirc.gov/documents/public/NJSP Guide to Intelligence Led Policing.pdf; S Mallory, The Concept of Asymmetrical Policing. IPES Working Paper o/12, September 2007; Ratcliffe 2016 Ibid.; and San Antonio Police Department, Intelligence Led Policing (2016) at http://www.sanantonio.gov/SAPD/IntelligenceLedPolicing.aspx
} 
Submitted draft

from the community-focused initiatives that traditionally have dominated in public policing. 82

\section{Legislative clarity}

Nick Tilley's representation of a typology of disruption as a 'specific form of ILP', ranges from reducing opportunities for offending (for example, by closing down businesses dealing in illicit goods) to sowing the seeds of distrust amongst offenders (for example, by feeding out disinformation through informers. He highlights that though these methods have huge appeal for the police, their use is rarely tested in criminal courts, and that raises important questions of public accountability, of trust in the police institution, and around the notion of personal liberty. ${ }^{83}$ Peter Gill and Christopher Murphy have issued similar warnings about the dangers represented by these kinds of shifts in the normative aims of public policing in late modernity. ${ }^{84}$

More than 20 years ago Peter Waddington argued that the reactive / responsive approach was more legitimate than available alternatives because the standard trigger for police action is public concern. 85 More recently, Mike Maguire has argued that reactive policing delivers both societal and financial benefits; the police involve themselves in the lives of citizens only when the latter decide that a social situation has become so intolerable that it demands an intervention: whereas ILP approaches often are open-ended and prioritize 'agendas set by the police'. ${ }^{86}$

\footnotetext{
82 A James, 2013 \& 2016 Ibid.

83 See N. Tilley Ibid.

84 See P. Gill, Rounding up the Usual Suspects (Ashgate 2000); and C. Murphy Ibid.

85 PAJ Waddington Calling the Police: The Interpretation of, and Response to, Calls for Assistance from the Public, (Avebury, 1993).

${ }^{86} \mathrm{M}$ Maguire, Criminal Investigation and Crime Control in T. Newburn (Ed) Handbook of Policing, (2nd Edn, Willan 2008).
} 


\section{Submitted draft}

Practitioners may feel that these analyses over-simplify a complex set of interdependencies; efforts to resolve one aspect of an intractable problem often reveal other questions and problems but they should highlight that assessments of the social world often require a deeper understanding of its dynamics than an organisationally-consistent faith in tradition and orthodoxy can deliver. ${ }^{87}$ They also suggest to practitioners the need for greater objectivity in assessing the appropriateness and necessity for extraordinary policing methods; and the importance of robust and effective oversight of what essentially is extra-judicial police activity.

\section{Mission creep}

In some cases, increases in capacity have been accompanied by significant structural reforms. In the US, fusion centres - multi-agency intelligence sharing hubs, first seen in the military context - have flourished in the post-9/11 policing environment. Torin Monahan argues this has supported the 'mission creep' of America's law enforcement agencies, which have:

steadily ventured into ... domains which have very little, or nothing at all to do with the War on Terror ... Instead they have been used for a variety of other purposes, such as basic policing, spying on social movement organizations, or restricting legal public activities. 88

Robert Taylor and Amanda Russell argue that any reconfiguration of policing on

\footnotetext{
87 See A James, 2016 Ibid. and KC Wong, Policing in Hong Kong: history and reform (CRC Press 2016) for examinations of police culture in this context.

88 Cited in B Harbisher, Unthinking Extremism: Radicalizing Narratives that Legitimize Surveillance, Surveillance \& Society [2015] 13(3/4), 474.
} 
Submitted draft

militaristic lines, undermines its very essence because it 'confuses ... foreign threats ... [with] internal law enforcement and policing ... [which] has the potential to trigger civil liberty abuses through invasions of privacy and racial profiling' ${ }^{89}$ The ILPdriven interventions against environmental protestors in the US, Canada, and the UK described here, perhaps can be seen in that vein. These cases raise important issues of institutional legitimacy and of legal and procedural fairness. For many readers, they will also stimulate concerns about the professional competence and ethical predisposition of staff, and about the structural constraints within which those staff operate.

Beyond national intelligence-sharing arrangements, it is possible to discern an increasing internationalization of cooperation between police intelligence agencies. Monica den Boer argued that in the European setting; EU institutions' oversight and control mechanisms are not keeping pace with inter and intra agency intelligence sharing, which is expanding exponentially. She argued that 'considerable governance challenges lurk around the corner'.90 John Occhipinti shares den Boer's concerns, arguing that the mission creep of EU institutions like Europol and FRONTEX, should be a matter of much greater concern to jurists. 91

\section{Professional competence}

At the micro level, ILP requires professionalism and expertise. Not least a deep understanding of human behaviour; the complexities of social situations; individuals'

\footnotetext{
89 RW Taylor and AL Russell, The failure of police 'fusion' centers and the concept of a national intelligence sharing plan Police Practice and Research [2012] 13(2), 184.

$9^{\circ} \mathrm{M}$ den Boer, Counter-Terrorism, Security and Intelligence in the EU: Governance Challenges for Collection, Exchange and Analysis Intelligence and National Security [2015] 30(2-3), 402. ${ }^{11} \mathrm{~J}$ Occhipinti, Still Moving toward a European FBI? Re-examining the Politics of EU Police Cooperation Intelligence and National Security [2015] 30(2-3), 234; and APJCLE (2013).
} 


\section{Submitted draft}

strengths and weaknesses - their motivations and goals; and, ultimately, their trustworthiness. As the author discovered in his research into police intelligence practice, ${ }^{92}$ the requisite levels of professional knowledge and reflection often are in short supply in an institution conditioned over many decades to act and to react rather than to pause, to reflect; to seek both a deeper understanding of the social world and their and the institution's parts in it.

The cases examined here illustrate some of the ways that states and their agencies blur the lines between different forms of deviance; constantly redefining 'dangerousness'. They also call into question intelligence staffs' ability to reflect in sufficiently meaningful ways on principles such as the: proportionality; legality; subsidiarity; and necessity of the activities they plan or propose. That may be only natural. Kira Rønn has argued, those concepts inherently are 'vague, ambiguous, and prone to subjectivity'.93

In rational-legal bureaucratic structures like the police, the emphasis always is on the task in hand.94 One does not have to search very hard to find an example of the way in which closed environments can encourage a certain narrowness in thought and approach Commonly considered to represent one of the greatest failures of intelligence in the modern era, the UK's involvement in the Iraq War

\footnotetext{
${ }_{92}$ A James 2016 Ibid; and A James, The path to enlightenment: limiting costs and maximizing returns from intelligence-led policy and practice in public policing, Policing [2017] doi: 10.1093/police/paw050.

93 KV Rønn, Democratizing Strategic Intelligence? On the feasibility of an objective, decision-making framework when assessing threats and harms of organized crime Policing [2012] 7(1), 53. 94 See N Cope, Crime analysis: principles and practice in T. Newburn (Ed) Handbook of Policing (Willan 2003, 340); and A James 2016 Ibid.
} 
Submitted draft

demonstrated only too clearly the symbiotic links between, effectiveness, transparency, and accountability in intelligence practice. 95

Often, it seems that shortcomings are recognised only when things go so badly wrong that the veil of secrecy that surrounds the work is penetrated. 96 Peter Manning highlights that only rarely are intelligence staffs held to account for their work because their efforts, generally, are not 'concerned with producing trustworthy evidence for ... attorneys, judges, and juries'. Instead, their data and their observations 'stay in the room' and are used inter alia to direct resources, to inform crime reduction strategies and to 'feed discussions that socialize [arguably, condition] intelligence insiders'.97 Nancy Lewis argues that the most significant inhibitor of information-sharing is culture, which has reinforced the traditional insularity of policing. ${ }^{98}$ Arguably, these are conditions in which 'ways and means' might sometimes be afforded greater significance than regulation and due process.

There is some evidence that policymakers are beginning to recognise the need for meaningful change. Chris Hayes the chair of the Australian Parliamentary Joint Committee on Law Enforcement (APJCLE) has highlighted law enforcement and intelligence practitioners' frustrations with the 'limitations, challenges and hurdles' to intelligence practice commonly encountered by the Australian national security

\footnotetext{
95 See S Tully, The Chilcot Report on Iraq and lessons for Australia (2016). LSJ: Law Society of NSW Journal, (26), 78; Lord Butler, Review of Intelligence on Weapons of Mass Destruction Report of a Committee of Privy Counsellors (HMSO 2004); and J Chilcot, Report of the Iraq Inquiry (HMSO 2016).

${ }^{96}$ See for example: M Bichard, The Bichard Inquiry Report (HMSO 2004); and APJCLE, Australian Parliamentary Joint Committee on Law Enforcement Inquiry into the gathering and use of criminal intelligence (Secretariat of the Australian Federal Government 2013).

97 PK Manning, Democratic policing: case working and intelligence. Comparing the Democratic Governance of Police Intelligence: New Models of Participation and Expertise in the United States and Europe (Edward Elgar 2016, 180).

${ }_{98} \mathrm{~N}$ Lewis, Expanding surveillance: connecting biometric information systems to international police cooperation in E Zureik and M Salter (Eds.) Global Surveillance and Policing (Willan 2013, 97).
} 
Submitted draft

and law enforcement agencies. ${ }^{99}$ He said that the committee had brought to light:

Serious ... impediments to the flow of intelligence which produce ... an incomplete picture of criminal threats and undermine stakeholder confidence. Some law enforcement agencies hold reservations about sharing their own information and seem not to recognize the value added to that information when converted into intelligence and returned to them... [Lack] of a common approach to collecting, collating, analysing and disseminating criminal intelligence underpinning a common ethos. ${ }^{100}$

Contemporaneously, police leaders in the UK accepted the existence of the same kinds of shortcomings in their own intelligence systems; recommending inter alia that the institution needed to commit to 'consensus building; developing relationships with individuals and institutions outside the policing bubble'. ${ }^{101}$ Taken together, these statements suggest that insiders seem to accept the need for change. ${ }^{102}$

\section{The silver bullet}

Any discussion of 'extraordinary' policing methods must acknowledge the susceptibility of the police to the lure of 'silver-bullet' type solutions to seemingly intractable, problems. The UK's National Intelligence Model, which routinely is lauded as the template for ILP success, delivered far less than the rhetoric

\footnotetext{
99 APJCLE Ibid. 100 Cited in APJCLE Ibid.

101 Cited in A James 2016 Ibid.

102 See also OSCE, Intelligence-led policing (2016). Available at http://polis.osce.org/library/f/5113/4618/OSCE-EU-EVT-5113-EN-4618.pdf Accessed 14/9/2017; and BA Jackson, Strengthening Trust between Police and the Public in an Era of Increasing Transparency (RAND Corporation, 2015).
} 


\section{Submitted draft}

suggests. ${ }^{103}$ Interestingly, the model largely avoided external review and, though it remains a factor in British policing (albeit in a much-amended form), it has faded into the background without changing UK policing very much; even if the rhetoric suggests otherwise. Arguably, the philosophies underpinning the model have had much greater impact elsewhere in the world..$^{104}$

A persuasive case can be made for strategies that emerge from rigorous and transparent processes of intelligence collection, validation, and selection, so that policing's scarce resources are used, intelligently. However, scholarly literature about the effectiveness, efficiency and legitimacy of ILP seems to be rather limited. In particular, there is a relative paucity of published empirical research into ILP. Beyond the rather obvious challenge of solving any complex problem in hierarchical, rational-legal bureaucracies, ILP may not be the answer to policing's ills in this context because it demands levels of professional knowledge, expertise, and reflection that currently are in short supply in the public police. ${ }^{105}$

That is less a commentary on the ability of individual practitioners as it is on the willingness or the ability of the police executive to help intelligence practitioners to overcome the structural barriers that limit their influence over the wider organization and wider socio-political issues such as the direction and control of the public police.

\footnotetext{
103 See P Amey; C Hale, and S Uglow, Development and Evaluation of a Crime Management Model (Home Office Police Research Group 1996); and A James 2013 \& 2016 Ibid. 104 The rejection of a prophet in their own land is a long-established, well-known and well-understood phenomenon. See for example H Brady, Europol and the European Criminal Intelligence Model: a non-state response to organized crime Policing [2008] 2(1), 103. 105 See IP Stanier, Contemporary organizational pathologies in police information sharing: new contributions to Sheptycki's lexicon of intelligence in policing (Doctoral dissertation, London Metropolitan University 2013); and A James 2013 \& 2016 Ibid.
} 
Submitted draft

\section{Conclusions}

Post 9/11, nations increasingly have trusted ILP for the defence of the state and the protection of citizens. ILP has been embraced across the world as the most effective way of combating terrorism and controlling transnational organised crime. The police institution's faith in the merits of ILP, not least its action-orientation, is culturally and organizationally consistent but its apparent success seems, at least in part, a triumph of marketing and branding. In assessing the utility of ILP, some agencies seem to under-appreciate its threat to long-established legal and ethical norms. Some trends in those developments can be discerned.

There has been: a shift towards the professionalisation of police intelligence practice; a formalisation of multi-agency law enforcement intelligence-cooperation (for example, in the form of fusion centres); the internationalisation of intelligencecooperation between police agencies and other partners; and a significant expansion in the use of what formerly were considered 'extraordinary' policing methods. Some may consider that, in totality, this is no more than is necessary to address the increasing dangerousness of the social world but these developments have significant implications for legislators, for policymakers, and for international law.

The professionalization of intelligence practice, the cornerstone of ILP, increasingly relies on the development and refinement of data collection, data mining, and intelligence analysis techniques and that has significant implications for privacy and for citizens' rights. Applying these techniques tests the capacities and capabilities of staffs who employ them. As the cases explored here show, the application of important principles like proportionality, subsidiarity, and necessity 


\section{Submitted draft}

always are based upon subjective judgements. Problems may emerge even when legislative and constitutional clarity exists.

ILP requires a particular set of skills: a deep knowledge of law and regulation and an innate respect for human rights. It also requires appreciation of the capabilities and limitations of investigative technologies. In the information age, police departments and intelligence practitioners need to reflect upon the real utility of concepts such as 'need to know' and 'neither admit nor deny', which for so long have been central to decision-making and which always have mitigated efforts to make that practice more transparent. ${ }^{106}$ Above all, task-focused practitioners must recognise their wider responsibilities to principles such as fairness and transparency and prioritise due process. Effective and intrusive extra-institutional oversight is needed so that rule infractions are identified and sanctions applied when necessary. Without that kind of oversight and scrutiny, public confidence in the policing institution is bound to diminish.

An analysis of state controls was beyond the scope of this analysis but some common developments in the cases examined are obvious. In the modern era, governments have responded to the threat of organized crime and terrorism by enacting more, and more far-reaching, controls. Normatively, officials argue that change is necessary to buttress the state and to keep citizens safe but calculations of security needs, invariably raise questions such as 'How much security do citizens

\footnotetext{
${ }^{106}$ When used by governments and their agencies in the context of intelligence practice, 'need to know' refers to the restriction of classified data to those who have a specific, officially-authorised, need for it. First used by the United States' Central Intelligence Agency in the Cold War Era, 'neither confirm nor deny' has become the standard response from governments around the world, to deflect questions about their clandestine activities.
} 
Submitted draft

require?' and 'Do extant or future threats warrant the surrender of traditional liberties and freedoms'? Answers to those questions always are politically, socially and culturally contingent but the cases studied here suggest a propensity to privilege the interests of the state over the rights and freedoms of ordinary citizens. These cases show that what once were considered extraordinary methods, increasingly are being used in the public policing milieu for ordinary policing purposes. Their use threatens long-cherished rights and freedoms; particularly when the methods are employed inappropriately or disproportionately. Higher-level norms (expressed in constitutions, charters, conventions, or the like) are meant to safeguard citizens' rights. Against that background, some may feel that cross-jurisdictional, supra-national, harmonization of ILP-related law and regulation, consistent with those norms, will provide citizens with the protections they need. Though an international consensus on that point, largely has eluded the efforts of policymakers.

In our imperfect world, perhaps a more realistic goal is a series of nationspecific arrangements that deliver workable compromises that more obviously privilege citizens' constitutional rights to security and liberty. The challenge of achieving even such a limited goal should not be underestimated but such a move might perhaps add measures of verifiability and accountability to processes that, at least for the short term, appear to be able to resist efforts to control them. 
Submitted draft

\section{Bibliography}

Apap J and Anderson M (Eds.) Police and Justice Co-operation and the New European Borders (Kluwer Law International 2002).

APJCLE, Australian Parliamentary Joint Committee on Law Enforcement Inquiry into the gathering and use of criminal intelligence (Secretariat of the Australian Federal Government, 2013).

Amey P; Hale C and Uglow S, Development and Evaluation of a Crime Management Model (UK Home Office Police Research Group 1996).

Anderson D, A Question of Trust - Report of the Investigatory Powers Review (Anderson 2015).

Balko R, Surprise! Controversial Patriot Act power now overwhelmingly used in drug investigations. Washington Post online at

https://www.washingtonpost.com/news/the-watch/wp/2014/10/29/surprisecontroversial-patriot-act-power-now-overwhelmingly-used-in-drug-investigations/ (29 October 2014).

Barrera J, RCMP intelligence centre compiled list of 89 indigenous rights activists considered 'threats'. National News at http://aptn.ca/news/2016/11/08/rcmpintelligence-centre-compiled-list-of-89-indigenous-rights-activists-consideredthreats/ (8 November 2016).

Bichard M, The Bichard Inquiry Report (HMSO, 2004).

Bloss WP, Transforming US police surveillance in a new privacy paradigm, Police Practice and Research: An International Journal [2009] 10(3).

Brady H, Europol and the European Criminal Intelligence Model: a non-state response to organized crime, Policing [2008] 2(1).

Brodeur J-P, High and Low Policing: Remarks about the Policing of Political Activities, Social Problems [1983] 30(5).

Brodeur J-P, The Policing Web (Oxford University Press 2010).

Butler Lord, Review of Intelligence on Weapons of Mass Destruction Report of a Committee of Privy Counsellors (HMSO 2004).

Carozza PG, Subsidiarity as a structural principle of international human rights law. American Journal of International Law [2003] v101.

Chilcot J, Report of the Iraq Inquiry (HMSO 2016).

Churchman CW, Wicked problems, Management Science [1967] 14(4). 
Submitted draft

Cooper G, Bob Lambert, undercover cops, and the awful cost of sleeping with the enemy. Daily Telegraph (online) at http://www.telegraph.co.uk/news/uknews/lawand-order/11185926/Bob-Lambert-undercover-cops-and-the-awful-cost-ofsleeping-with-the-enemy.html (2016 October 25).

Delpeuch T and Ross JE (Eds.), Comparing the Democratic Governance of Police Intelligence: New Models of Participation and Expertise in the United States and Europe (Edward Elgar 2016).

den Boer M, Counter-Terrorism, Security and Intelligence in the EU: Governance Challenges for Collection, Exchange and Analysis, Intelligence and National Security [2015] 30(2-3).

den Hengst M and Staffeleu E, Different Information Organizations to Produce the Same High Quality Intelligence: An Overview of the Police Forces in the Netherlands. Policing [2012] 6(2).

den Hengst-Bruggeling M, De Graaf B; and Van Scheepstal P, Modelling intelligenceled policing to identify its potential. European Journal of Policing Studies [2014] 1(3).

Dowley M, Government Surveillance Powers under the USA Patriot Act: Is It Possible to Protect National Security and Privacy at the Same Time - A Constitutional Tug-of-War, Suffolk University Law Review [2002] 36(1).

EFF, Peekaboo, I See You: Government Authority Intended for Terrorism is used for Other Purposes [2014] Available at https://www.eff.org/deeplinks/2014/10/peekaboo-i-see-you-government-usesauthority-meant-terrorism-other-uses

Ericson R, Ten uncertainties of risk-management approaches to security. Canadian Journal of Criminology and Criminal Justice, [2006] 48(3).

Gieseke J, The Stasi and East German Society: Some Remarks on Current Research. Bulletin of the German Historical Institute, [2014] Supplement 9.

Gill P, Rounding up the Usual Suspects (Ashgate 2000).

Harbisher B, Unthinking Extremism: Radicalizing Narratives that Legitimize Surveillance, Surveillance \& Society [2015] 13(3/4).

Harfield, C \& Harfield, K, Intelligence, Investigation, Community and Partnership (Oxford University Press 2008).

HMIC, Inspection of undercover policing in England and Wales (HMIC 2014). 
Submitted draft

Husabø EJ \& Bruce I, Fighting Terrorism through Multilevel Criminal Legislation: Security Council Resolution 1373. EU Framework Decision on Combating Terrorism and their Implementation in Nordic, Dutch and German Criminal Law (Martinus Nijhoff 2009).

Husabø EJ, Counterterrorism and the Expansion of Proactive Police Powers in the Nordic States, Journal of Scandinavian Studies in Criminology and Crime Prevention [2013] 14(1).

Innes M \& Sheptycki J, From detection to disruption: intelligence and the changing logic of police crime control in the United Kingdom. International Criminal Justice Review [2004] 14(1).

Jackson BA, Strengthening Trust between Police and the Public in an Era of Increasing Transparency (RAND Corporation 2015).

James A, Examining Intelligence Led Policing (Palgrave Macmillan 2013).

James A, Understanding police intelligence work (Policy Press 2016).

James A, The path to enlightenment: limiting costs and maximizing returns from intelligence-led policy and practice in public policing, Policing [2017] doi: 10.1093/police/paw050.

Johnson LK (Ed), The Oxford Handbook of National Security Intelligence (Oxford University Press 2010)

Jones T; van Steden R; and Boutellier H, Pluralization of policing in England \& Wales and the Netherlands: exploring similarity and difference, Policing \& Society [2009] 19(3).

Kleinig J, Handled with discretion: ethical issues in police decision making (Rowman and Littlefield 1996).

Klimoski RJ, From the editor: Becoming a prophet in our own land, Academy of Management Learning \& Education [2007] 6(4).

Kruisbergen EW; de Jong, D; and Kleemans ER, Undercover Policing: Assumptions and Empirical Evidence, British Journal of Criminology [2011] 51.

Kruisbergen EW; Kleemans ER; and de Jong D, Controlling Criminal Investigations: The Case of Undercover Operations, Policing [2012] 6(4).

Lewis N, Expanding surveillance: connecting biometric information systems to international police cooperation in E Zureik and M Salter (Eds.). Global Surveillance and Policing (Willan 2013).

Mallory S, The Concept of Asymmetrical Policing (IPES Working Paper o/12, 
Submitted draft

September 2007).

Manning PK, Police Lying, Journal of Contemporary Ethnography [1974] 3(3).

McKay S, Covert Policing Law and Practice (2 ${ }^{\text {nd }}$ edn, Oxford University Press, 2015).

Murphy C, Securitizing' Canadian Policing: A New Policing Paradigm for the Post 9/11 Security State? Australian \& New Zealand Journal of Criminology [2004] April $37(1)$.

Mythen G \& Walklate S, Criminology and terrorism which thesis? Risk society or governmentality? British Journal of Criminology, [2006] 46(3).

Newburn T (Ed), Handbook of Policing (2 ${ }^{\text {nd }}$ edn Willan 2008).

New Jersey State Police, Practical Guide to Intelligence-led Policing (2006).

Available at

https://www.ncirc.gov/documents/public/NJSP Guide to Intelligence Led Polici $\underline{\text { ng.pdf }}$

Occhipinti J, Still Moving toward a European FBI? Re-Examining the Politics of EU Police Cooperation, Intelligence and National Security [2015] 30(2-3).

OSCE (2016). Intelligence-led policing. Organisation for Security and Cooperation in Europe. Available at http://polis.osce.org/library/f/5113/4618/OSCE-EU-EVT-5113EN-4618.pdf

Ratcliffe JH, (Ed) Strategic Thinking in Criminal Intelligence (Federation Press 2004).

Ratcliffe JH, Intelligence-Led Policing (2 ${ }^{\text {nd }}$ edn, Routledge 2016).

Reiner R, The Politics of the Police (4th edn Oxford University Press 2010).

Reuss-Ianni E, Two cultures of policing: Street cops and management cops (Transaction Publishers 1993).

Rønn KV, Democratizing Strategic Intelligence? On the feasibility of an objective, decision-making framework when assessing threats and harms of organized crime, Policing, [2012] 7(1).

Ross JE, The Place of Covert Surveillance in Democratic Societies: A Comparative Study of the United States and Germany. American Journal of Comparative Law, [2007] 55(3).

Royal Canadian Mounted Police, Project SITKA: serious criminality associated to large public order events with national implications (RCMP 2015). 
Submitted draft

Rowe M; Westmarland L; \& Hougham C, Getting behind the blue curtain, Accountability of Policing, [2015] 29.

RUSI, A Democratic Licence to Operate Report of the Independent Surveillance Review (RUSI 2015).

San Antonio Police Department, Intelligence Led Policing (2016). Available at http://www.sanantonio.gov/SAPD/IntelligenceLedPolicing.aspx

Stanier IP, Contemporary organizational pathologies in police information sharing: new contributions to Sheptycki's lexicon of intelligence in policing (Doctoral dissertation, London Metropolitan University 2013).

Steeves V \& Piňero V, Privacy and Police Powers: Situating the Reasonable Expectation of Privacy Test. Canadian Journal of Criminology and Criminal Justice [2008] 50(3).

Strandh V \& Eklund N, Swedish Counterterrorism Policy: An Intersection Between Prevention and Mitigation? Studies in Conflict \& Terrorism [2015] 38(5).

Terpstra J \& van der Vijver K, The Police, Changing Security Arrangements and Late Modernity: The Case of the Netherlands, German Police Studies [2006] 5(1).

Taylor RW \& Russell AL, The failure of police 'fusion' centers and the concept of a national intelligence sharing plan, Police Practice and Research [2012] 13(2).

Tully S, The Chilcot Report on IRAQ and lessons for Australia, LSJ: Law Society of NSW Journal [2016] v26.

UK Audit Commission, Helping with enquiries: tackling crime effectively (Audit Commission 1993).

UKOSC, Annual Report of the Chief Surveillance Commissioner to the Prime Minister and to the Scottish Ministers (OSC 2016).

Waddington PAJ, Calling the Police: The Interpretation of, and Response to, Calls for Assistance from the Public (Avebury 1993).

Walsh DPJ \& Conway V, Police Governance and Accountability: Overview of Current Issues, Crime, Law and Social Change [2011] 55(2).

Walsh DPJ, Intelligence and intelligence analysis (Routledge 2011).

Wong KC, Policing in Hong Kong: history and reform (CRC Press 2015).

Zureik E with Hindle K (2004). Governance, Security and Technology: the case of biometrics, Studies in Political Economy [2004] 73. 